\title{
“Clásico, manierista y posclásico", el relato en el cine de Hollywood
}

\author{
Por Julio César Goyes Narváez ${ }^{1}$ \\ Universidad Nacional de Colombia
}

González Requena, Jesús. (2006). Clásico, manierista y posclásico: los modos del relato en el cine de Hollywood. Valladolid: Castilla.

En su último libro Clásico, manierista y posclásico: los modos del relato en el cine de Hollywood, Jesús González Requena, catedrático de Comunicación Audiovisual, Coordinador del Doctorado en Teoría, Análisis y Documentación Cinematográfica en la Universidad Complutense de Madrid y presidente de la asociación cultural Trama y

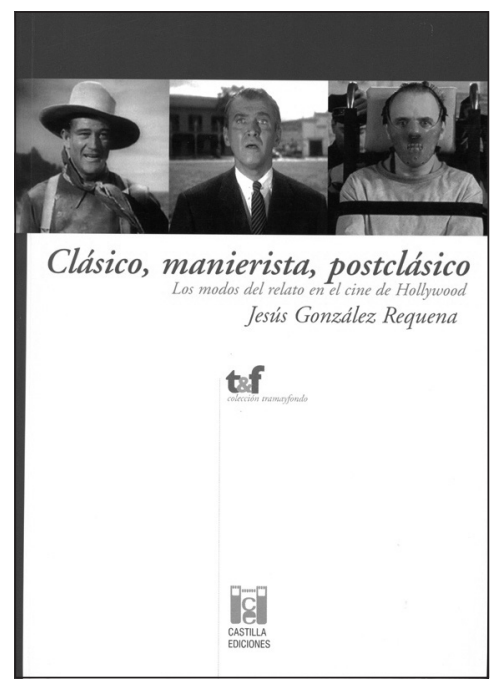
Fondo, observa a través del análisis textual, el psicoanálisis y la antropología, cómo en películas emblemáticas de la historia del cine: La Diligencia (John Ford, 1939), Vértigo (Alfred Hitchcock, 1958) y El silencio de los corderos (Jonathan Demme, 1991), la eficacia del relato simbólico ha sido desarticulada por la estética especular y el universo psicótico. Una escritura de la sospecha, en suma, puesto que constata el arte excepcional que fue el cine clásico americano, expuesto hoy a la lente homogenizadora que lo clasifica en un único sistema de representación cinematográfico: consumista, acrítico y mistificador. Los estudiosos, por otro lado, no han logrado ver la crisis de la narración y de los ensayos vanguardistas, ni la deconstrucción cinematográfica que comenzó con el manierismo, hasta el estado actual del cine posclásico, que fulmina el relato mítico y detiene la eficacia simbólica que convierte la pulsión (energía violenta y destructiva) en deseo.

\footnotetext{
${ }^{1}$ Profesor e investigador del Instituto de Estudios en Comunicación y Cultura -IECOde la Universidad Nacional de Colombia. Correo-e: jcgoyesn@unal.edu.co.
} 
$\mathrm{Al}$ analizar las tres películas citadas y comparar las tres formas del relato, el autor encuentra que el cine clásico, por ejemplo, pone en funcionamiento mecanismos simbólicos que hacen vivenciar al espectador focalizando su deseo a través del deseo del héroe; el relato manierista, en cambio, se vale de la apariencia clásica como un espejo que devuelve la imagen distorsionada, escritura engañosa del yo escindido. Por el ello el destinador construye un relato ficticio en torno a un héroe que ya no transporta una palabra verdadera, sino el artificio de una escena dentro de otra, desplazando la tarea del héroe hacia una atención en la escritura misma del audiovisual. Si en el relato clásico el héroe es capaz de erigirse como padre simbólico, en el manierista esa sujeción desaparece, abriéndose un vacío cuya escritura es el vértigo que el espectador goza. Finalmente, observa que el destinador, en el relato posclásico, es el psicópata, pues el héroe que hace el bien desaparece y en su lugar encontramos la eficacia del mal (Hanníbal Lecter). La palabra del psicópata, ausente de simbolismo, no guía sino devora, arrastra a lo oscuro de la condición humana. En la escena de la autopsia donde está presente la agente Starling, en el Silencio de los corderos, ésta encuentra en el lugar donde se articula justo la palabra la polilla de la muerte.

Con respecto al cine europeo, cuyas ataduras con el americano son mayores que las diferencias, el autor escribe:

Compartiendo una común posición deconstructura frente al universo simbólico del relato clásico, el film posclásico europeo se conformará como un cine del distanciamiento y la escritura, mientras que el americano, en cambio, se configurará como un cine de la inmediatez y del espectáculo. Pero, en cualquier caso, por una u otra vía, ambos se alejarán igualmente de esa distancia justa -ni excesiva en la lejanía, ni excesiva en la proximidad- que constituyera el rasgo mayor de la puesta en escena clásica. De esa distancia justa, recordémoslo, que venía determinada por la ley simbólica que hacía posible la constitución del deseo y del sujeto. Frente a ella, la frialdad del cine posclásico europeo será la de un deseo en continuo desvanecimiento, pues siempre incapaz de cristalizar-de ahí la anomia radical que reina en los universos de Antonioni, Bergman o Godard-, mientras que el extremo ardor del hollywoodiense será el de uno que se desintegra en la misma medida en que se abisma en un goce extremo y letal -Lynch, Cronenmberg, Demme. (2006: 584).

El libro del profesor González Requena consta de dos partes: la primera, que hace una inversión pedagógica en la forma de afrontar la 
lectura, trata el análisis de los filmes con las ilustraciones pertinentes y precisas de las películas en cuestión, y sólo después encontramos el discurso teórico y metodológico. A propósito de esta última parte, dedicada a la Teoría del relato, encontramos un debate argumentado y ágil sobre los límites ("la ceguera") del pensamiento semiótico y la narratología cognitivista para encargarse del texto fílmico, puesto que la reducción comunicativa acaba con la experiencia subjetiva, emocional y creativa del espectador.

Jesús Gonzáles Requena también es autor de La metáfora del espejo. El cine de Douglas Sirk (Hiperión, 1986); El discurso televisivo: espectáculo de la posmodernidad (Cátedra, 1988); El espectáculo informativo. O la amenaza de lo real (Akal, 1989); Eisenstein. Lo que solicita ser escrito (Cátedra, 1992); El spot publicitario. Las metamorfosis del deseo, (Cátedra, 1995); Léolo: La escritura en el umbral de la psicosis (La Mirada, 2000) (los dos últimos con Amaya Ortiz) y Los tres Reyes Magos: la eficacia del relato simbólico (Madrid, Akal, 2002). 
